\title{
Embankment Dam Seepage and Slope Stability Analysis: The Case of Arjo-dedessa Dam, Ethiopia
}

\author{
Ayansa Gamachu Aga \\ Civil Engineering Department, College of Engineering, Mettu University, Mettu, Ethiopia \\ Email address: \\ ayansagemechu4@gmail.com
}

\section{To cite this article:}

Ayansa Gamachu Aga. Embankment Dam Seepage and Slope Stability Analysis: The Case of Arjo-dedessa Dam, Ethiopia. Journal of Civil, Construction and Environmental Engineering. Vol. 6, No. 4, 2021, pp. 104-109. doi: 10.11648/j.jccee.20210604.11

Received: June 25, 2021; Accepted: July 10, 2021; Published: August 2, 2021

\begin{abstract}
Dams have one of the greatest significant roles in operating water resources. Seepage and slope stability failures cause completely failure of embankment dams. Dam disasters not only hazard community safety, they also can cost our economy millions of dollars in compensations. The study area is found in Oromia regional state between East Wollega and Bunno Bedele Zone. The dam is located on Dedessa River, tributary of Blue Nile River. Analysis of seepage quantity was done by Darcy's phreatic line, and SEEP/W software model for both homogeneous and zoned dam. The expected quantity of seepage estimated with the SEEP/W software model analysis that includes foundation seepage is $6.6^{*} 10^{-6} \mathrm{~m}^{3} / \mathrm{sec}$. Slope stability study is to contribute to the safe and economic design of upstream and downstream slope of the dam. The factory of safety obtained by Morgenstern-Price method for end construction is $(\mathrm{FOS}=1.99)$, for steady state $(\mathrm{FOS}=2.03)$ and rapid drawdown $(\mathrm{FOS}=2.91)$. However, at the design document shell material hadn't been designed properly. Finally the paper concluded that the likely corrective measures for seepage controls are impermeable blanket, grouting, and the downstream slope miscarriage by eliminating the pathetic zone and seal with like graded quantifiable, regular repairs and shield the downstream slope with grasses.
\end{abstract}

Keywords: Limit Equilibrium Methods, Phreatic Line, Seep/w, Slop/w, Steady State

\section{Introduction}

A dam is a obstacle that blocks the flow of water and produces a reservoir. The water kept in the reservoir is used for various purposes, such as irrigation, municipal and industrial supply, hydropower and recreation. Effects of dam failure on man and environment are well known. These require both preventive and mitigation measures. Dam failures may occur due to a variation of causes. The most common causes of dam failure are leakage and piping, overtopping, spillway erosion, extreme deformation, sliding, gate failure, faulty construction, and earthquake instability [13]. Major dams have some seepage through or around the environment as a result of water moving through the soil structure. Many seepage problems and failure of earth dams have occurred because of insufficient seepage control measures or poor clean up and preparation of the foundations and abutments. A change in vegetation is another indicator of seepage. Seepage causing problems that can lead to dam failure are piping through dam body or foundation and sloughing of downstream side of dam [9].

According to Yazdanian report [14] Slope stability analysis of earthen dam is dependent to many parameters which must consider in design and construction. Stability of these structures is composed of many ambiguities relevant to lack of precise geotechnical parameters. Investigating of slope stability of earthen dam slopes is an advanced procedure which has been shown to lead to a more economical design by many researchers which states that the cases that computed safety factor without modeling uncertainties is more than reality value. These methods do not consider many uncertainties in their computation.

\subsection{Statement of the Problem}

All embankment dam functions safely under routine everyday operation and rare conditions. The practical seepage problems are not easily changeable into an equivalent numerical complement because of the heterogeneity of the natural soils and the varying boundary conditions. Based on the parametric sensitivity analysis, both 
the seepage and stability studies have brought out the importance of considering the coupled effects on the overall stability of the earth dam. It is concluded that the coupled analysis is a prerequisite for the design and performance evaluation of the earth dam under all conditions of seepage and stability [2].

Arjo-Dedessa project is designed for the irrigation purpose to deliver irrigation facility to 80,000 ha of land for sugar cane development, to promote and encourage sustainable agricultural production. To attain this, dam failure due to the quantity of seepage and slope instability will be effectively mitigated and analyzed using various methods. When a dam fails, resources must be devoted to the prevention and treatment of public health risks as well as the resulting structural consequences [6].

\subsection{General Objective}

The general aim of this study is to assess seepage and slope stability analysis of Arjo-dedessa embankment dam.

\subsection{Specific Objectives}

1) To assess the quantity of seepage through the dam body and foundation.

2) To assess the static stability of the upstream and downstream of the dam.

3) 3) To put the suitable corrective measures for the outcome of the study.

\subsection{Scope of the Study}

This study is a step towards assessing embankment dam failure, highlighting to seepage and slope stability analysis. In addition, to put suitable mitigate measure for the outcome of study and checks seepage quantity and slope stability analysis. The research does not include the hydraulic, structural failure (settlement and deformation, earthquake analysis).

\subsection{Significance of the Study}

The study provides relevant information for the decision makers in the design of the dam and other developmental activities and various beneficial to the community at the dam. This information helps those bodies for taking appropriate decision making and under take effective remedial action to minimize failure of the dam and increasing the agricultural production for the return period of the dam and to be used as a guide in planning, designing new similar projects and redesign and maintenance of failed and existing dams. The main significance is the safe guarding of safety of the dam.

\section{Literature Review}

\subsection{Embankment Dam Considerations}

Most of the time locally available embankment material governs the type of embankment dam. If the site is dominated by only one type of material (soil) the design will consist of a homogeneous embankment. If it is impervious soil, a homogeneous embankment with only small amount of pervious material to control the internal erosion will be selected. If it is pervious material (sand or gravel), a dam with a very thin core may be used where enough impervious material is available to make a core; otherwise an impervious facing may be constructed. In homogeneous fill dams the slopes are flattened, which contributes to the seepage control by descending the velocity of the percolating water. For the case where varied material is available at the site a zoned dam which incorporates the material available on the site into the embankment will be selected. A zoned dam is a rolled fill dam composed of several zones that increases in permeability from the core towards the outer slopes [12].

\subsection{Embankment Dam Failure}

According to Redda report [7] An embankment dam is a massive artificial dam that are more common than any other type of dams because of various reasons like the use of ordinary technology construction method utilizing cheap raw soil materials and subsurface materials, no need of a particular valley shape etc. The geometry of embankment dams depends on burrowed soil materials, subsurface conditions and type of construction.

Earth Dams are constructed where the foundation or underlying material or rocks are weak to support the masonry dam. Earth dams are less rigid and hence more susceptible to failure. The various causes leading to the failure of earth dams can be grouped into three categories [10].

\subsubsection{Modes of Seepage Failure}

The failure mode of an embankment dam is directly connected with the type of cause of failure and the type of the dam. Abnormal increases of seepage quantity and leakage of turbid water are the visual indication of ongoing erosion. Piping effect is a result from the intergranular flow of water. Internal erosion is a very common cause of embankment failure in hydraulically fractured structures such as cracks and joints [8].

\subsubsection{Seepage Analysis Methods}

There are various methods of Seepage analysis this are;

a) By Darcy's law -phreatic line analysis

Phreatic line (seepage line) or saturation line is the line at the upper surface of the seepage flow at which the pressure is atmospheric.

b) By Flow Net analysis

A flow net is a graphical symbol of flow field and comprises a family flow lines and equipotential lines.

c) By SEEP/W Software Model

$\mathrm{SEEP} / \mathrm{W}$ is software which used to solve the practical seepage problems. This is a part of the most popular geotechnical software called GeoStudio [4].

a) Seepage Control through dam embankment

The three methods for seepage control in embankment are:- 
i. Use of filters: - Every seepage discharge face, both internal and external, that could be susceptible to piping and heave, must be covered with filters that permit the water to escape freely but hold the particles in place.

ii. Use of impervious Core: - Seepage reduction in embankment dams is done by providing an impervious core at the middle of the section. Most of the energy due to the stored water is consumed by seepage through the core, which is subject to excessive seepage forces in the process.

iii. Use of drain:-Chimney drains the most effective seepage control measure in earth dams, extending along the $\mathrm{d} / \mathrm{s}$ face of the impervious core in a zoned dam section, or placed in the heart of a homogeneous dam section, and connected to the $\mathrm{d} / \mathrm{s}$ drainage blanket for drainage [3].

b) Seepage Control through dam foundations

The foundation and abutment of dams, which are usually stable under the influence of natural ground water flow, may develop a tendency to internal erosion and piping due to the change ground-water regime on reservoir impoundment. The measure for under-seepage control through the foundation include a positive cutoff formed in an excavation up to an impervious stratum and backfilled with compacted impervious material, concrete cutoffs walls, grout curtain, slurry trench cutoff (earth backfilled), sheet piles, u/s impervious blanket, vertical drains, relief wells and filter trenches. On the other hand, methods are commonly used to control seepage through pervious, Seepage reducing methods comprise trench cut-offs, u/s impervious blankets, concert diaphragms, slurry trench cut-offs, and grout curtains [3].

\subsubsection{Slope Stability Analysis}

Slope Stability analysis is carried out in order to determine the factor of safety of a potential (shear) failure surface. The factor of safety is defined as the ratio of the resisting force or moment to the driving force or moment. The computations for the factor of safety should be based on the most unfavorable condition under which the tests for the determination of the material properties (parameters) are to be carried out [11].

\subsubsection{Slope/w Software}

SLOPE/W, developed by GEO-SLOPE International Canada, is used for slope stability analysis. This software is based on the theories and principles of the limit equilibrium methods. In this study, SLOPE/W has been applied separately and together with SEEP/W, other software program, which computes the pore pressure distributions, based on finite elements mesh and groundwater seepage analyses. Finally, the pore pressure distributions were coupled with slope stability analysis and FOS was determined. The software SLOPE/W computes factor of safety for various shear surfaces [1].

\section{Materials and Methods}

\subsection{Description of the Study Area}

Arjo-Dedessa dam is found in between East Wollega and Jimma Zones of Oromia Regional State. The project area is located between $8^{\circ}-30$ ' $-00^{\prime \prime}$ to $8^{\circ}-40^{\prime}-00^{\prime \prime} \mathrm{N}$ Latitude and $36^{\circ}-22^{\prime}-00^{\prime \prime}$ to $36^{\circ}-43^{\prime}-00^{\prime \prime}$ E Longitude. Arjo-Dedessa catchment area up to the proposed dam is about 5,632.64 square kilometers and the catchment area up to confluence with Abay River 34,000 square kilometers [6].

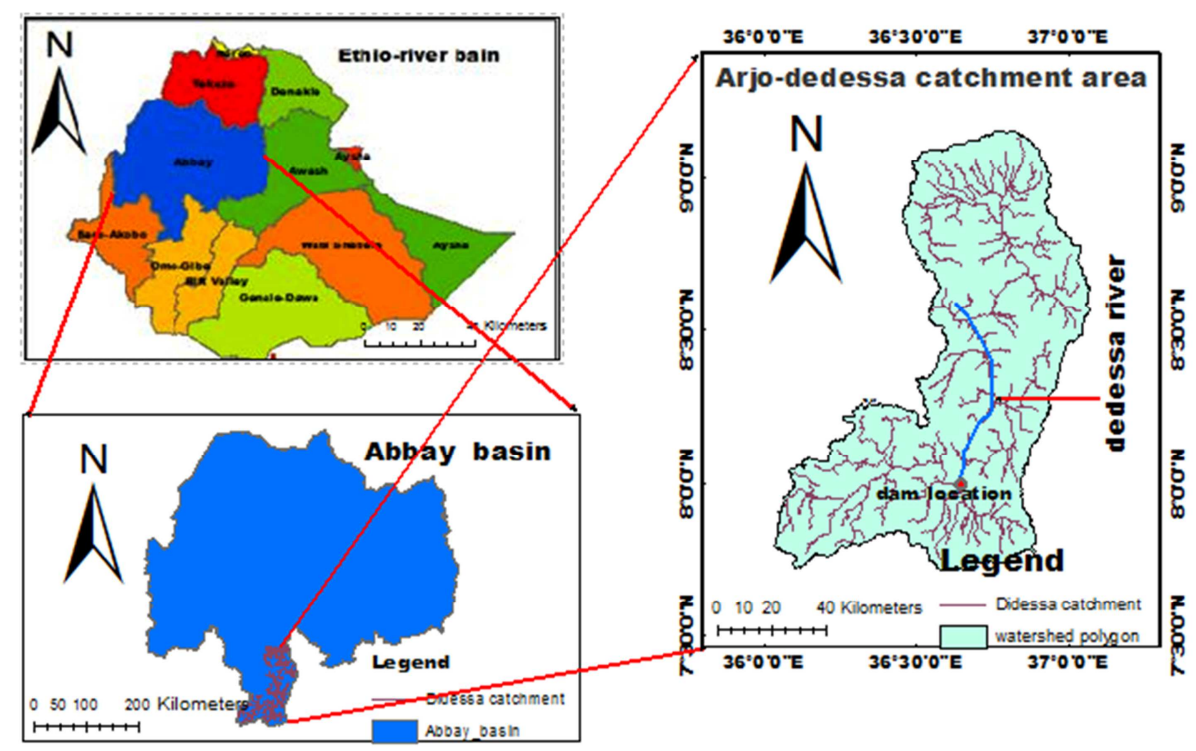

Figure 1. Geographical Location of the Study Area.

\subsection{Tools}

The tools used for seepage and slope stability analysis are: a) Digital camera-to collect the dam body and its appurtenant structural pictures.

b) Tape meter- for measuring length, slope and area of the basin. 
c) Global positioning Satellite (GPS) - to check coordinates of points.

d) Geo-studio-2012 -is software models-to analyze both seepage and slope stability.

e) AutoCAD-2016-To plot the geometry of the dam.

f) Ms. Excel-To compute the points on the phreatic line.

\subsection{Analysis of Data}

Analysis of the Arjo-dedessa embankment dam failure has been carried out by using analytical and mathematically by Geo studio software model.

\subsubsection{Analysis of Seepage}

a) Analysis by phreatic line

Phreatic line / seepage line / Saturation line is the line at the upper surface of the seepage flow at which the pressure is atmospheric. Seepage line is used to determine the quantity of water passing through the body of the dam and foundation. Now the analysis has been carried out both for Homogeneous and Zoned embankment dams. But actually Arjo-dedessa dam is a zoned dam with horizontal filter. The available data obtained from design document for estimating seepage are geometry of the dam and permeability coefficient of core and shell material.

b) Analysis by SEEP/W software model

SEEP/W (Seepage for Windows) is a suitable tool that can be used to model the movement and pore-water pressure distribution within porous materials such as soil and rock.

The procedures followed to analyze the problem using this model are:-

i) Introducing the geometry of the dam and draw region

ii) Insert hydraulic conductivity of the material.

iii) Insert boundary condition that influence the seepage, head of water above it, and the location of seepage exit where pressure head will be zero.

iv) Locate the fluxes section where the result will be labeled

v) Verify/optimize the data given

vi) If the data have no error, solve the problem. Analysis of slope stability

Stability analysis of selected section of dam embankment has been carried out by using software SLOPE/W developed by GEO-SLOPE International Ltd. The software uses the general limit equilibrium (GLE) formulation for estimating the factor of safety in stability of upstream and downstream slopes for various loading conditions. The process of slope stability will be listed below.

i. Dam cross-sections.

ii. Specify analysis methods

iii. Specify slip surface analysis options

iv. Define Soil Properties

v. Solve and analyze result

\subsubsection{Analysis of Slope Stability}

Stability analysis of selected section of dam embankment has been carried out by using software SLOPE/W developed by GEO-SLOPE International Ltd. The software uses the general limit equilibrium (GLE) formulation for estimating the factor of safety in stability of upstream and downstream slopes for various loading conditions. The procedure of slope stability will be listed below [5].

i. Defining the geometry

ii. Specify the analysis methods

iii. Specify slip surface analysis options

iv Define Soil Properties

v. Solve and analyze result

\section{Result and Discussion}

\subsection{Analysis of Seepage}

Analysis of seepage has been carried out to assess the embankment dam catastrophe with highlighting on seepage and slope stability problem.

\subsubsection{Darcy's-law Phreatic Line}

Although Arjo-dedessa embankment dam is zoned type dam; the analysis has been used to estimate the expected quantity of seepage for homogeneous and zoned dam with drainage system.

i. Homogeneous Dam

Homogeneous dam analysis has been carried with provision of drainage system

The total seepage (Q) $=4.8^{*} 10^{-6} \mathrm{~m}^{3} / \mathrm{sec} / \mathrm{m}$ $* 537.11 \mathrm{~m}=2.6 * 10^{-3} \mathrm{~m}^{3} / \mathrm{sec}$

ii. Zoned earth dam

Zoned earth dam is type of an earth dam usually which is an economic and more stable dam.
The
total
${ }^{8} \mathrm{~m}^{3} / \mathrm{sec}$
seepage
$(\mathrm{Q})=4.7 * 10^{-}$

\subsubsection{Analysis by Seep/W Software Model}

For homogeneous dam, the result of the analysis using SEEP/W software model for the case of homogeneous dam is presented below. The analysis considered the dam with filter drainage system and neglected the impact of foundation seepage. Using SEEP/W software model requires the sets of parameters like; model section of the dam, permeability coefficient of material, the piezometer reading, boundary conditions and saturated water content. Its permeability coefficient has a value of $5^{*} 10^{-5} \mathrm{~cm} / \mathrm{sec}$.

The quantity of seepage passing through the dam body calculated for homogeneous dam with horizontal filter is $\left(4.8^{*} 10^{-6} \mathrm{~m}^{3} / \mathrm{s}\right)$. However, Arjo-dedessa dam was a zoned dam. In this study, the maximum value of seepage between zoned dam with horizontal filter including foundation $\left(6.6^{*} 10^{-6} \mathrm{~m}^{3} / \mathrm{s}\right)$. It can be noticed that the quantity and velocity of seepage during full reservoir level $\left(6.6^{*} 10^{-}\right.$ ${ }^{6} \mathrm{~m}^{3} / \mathrm{sec} / \mathrm{m}$ )greater than in case of current water level $\left(1.52 * 10^{-6} \mathrm{~m}^{3} / \mathrm{se} / \mathrm{m}\right)$ which indicate that the quantity and velocity of seepage increase with increasing height of water level in the upstream of the dam.

\subsection{Slope Stability Analysis}

The determination of factor of safety for the dam slope 
stability, under different cases of operations, is vital to ascertain the dam overall safety. The considered analytical methods in this study are Ordinary, Bishop's Simplified, and Janbu's Simplified and Morgenstern-Price methods. From the design document factor of safety derived the Morgensternprice method has been adopted. In this document the value of factor of safety analyzed using various methods but only the Morgenstern - price method was shown as below.

The least factor of safety calculated for end of construction at upstream $(\mathrm{FOS}=2.82)$ and at downstream $(\mathrm{FOS}=1.99)$ equated with the least tolerable safety factor provided by international standards ( $\mathrm{FOS}=1$ ).

Table 1. Comparison of the minimum FOS for different loading conditions.

\begin{tabular}{|c|c|c|c|c|c|}
\hline \multirow[b]{2}{*}{ Noo. } & \multirow[b]{2}{*}{ Loading condition } & \multirow[b]{2}{*}{ Critical Slope } & \multicolumn{3}{|l|}{ Minimum Factor of Safety } \\
\hline & & & $\begin{array}{l}\text { Computed at the previous study } \\
\text { (Morgenstern-price method) }\end{array}$ & $\begin{array}{l}\text { International } \\
\text { standards }\end{array}$ & $\begin{array}{l}\text { At design document (by } \\
\text { Morgenstern-price method) }\end{array}$ \\
\hline \multirow{2}{*}{ I } & \multirow{2}{*}{ End of construction } & $\mathrm{U} / \mathrm{S}$ & 2.82 & 1.0 & 1.416 \\
\hline & & $\mathrm{D} / \mathrm{S}$ & 1.99 & 1.0 & 1.589 \\
\hline II & Sudden draw down & $\mathrm{U} / \mathrm{S}$ & 2.9 & 1.3 & 2.346 \\
\hline III & Steady seepage reservoir full & $\mathrm{D} / \mathrm{S}$ & 2.03 & 1.5 & 2.020 \\
\hline
\end{tabular}

a) Steady Seepage state

This condition is developed when the water level is maintained at a constant level for sufficiently long time establishing seepage lines in the earth dam. Stability analysis of Arjo-Dedessa dam for steady seepage state has been carried out by considering head pond level at FRL and no water at tail of the dam. The stability of downstream slope under steady state has been checked without consideration of seismic loading.

b) Sudden Drawdown

In projects that incorporate an outlet of sufficiently large discharging capacity, either for irrigation releases downstream or for emergency depletion of reservoir, there may be a sudden drop in reservoir water level after a condition of steady state seepage is established in the embankment and foundations. Such rapid drawdown of the reservoir water surface does not allow the pore water pressures in the embankment fill to dissipate at the same rate as the fall in reservoir water surface. This condition then becomes critical for stability of upstream slope.

\subsection{Remedial Measures of the Case Study}

The seepage and stability analysis will be done using the dam geometry and soil properties data. From the field observation shows seepage has been physically observed at the berm of downstream face of the dam and Water was seen to be emerging out of downstream face of the coffer dam close to the diversion conduits and also the downstream side slope failure was observed. In order to reduce the hazard of embankment failure the corrective measure has been taken as below.

\section{a) Remedial measures for seepage}

During field visit shows seepage has been physically observed at the berm of downstream face of the dam and Water was seen to be emerging out of downstream face of the coffer dam close to the diversion conduits. Upstream coffer dam, that is to form an integral a part of main dam, has already been constructed embodying these diversion conduits. Seepage water is observed to be coming out of the downstream face of the cofferdam from a point located just above the embedded diversion conduit. Besides this concentrated seepage, water was seen to be coming out of cofferdam body at many other points, though in small quantities. The water seeping throughout the year that has an impact on their life, Therefore, it has fundamental importance to limit these problems related with seepage through it.

1) Mortaring at the contact between the embankment and the abutment. The interaction zone can be treated by cement grout.

2) Reasonable thickness of impermeable blanket of appropriate length is placed over the soft seepage areas at the downstream face of the dam as one of the remedial measures. This adds weight and provides a working platform for installation of relief wells at points of excessive seepage.

3) Berm control seepage is made by increasing the weight of the top stratum so that the weight of the berm plus top stratum is sufficient to resist uplift pressure and the water will not rise to the berm. Again, a seepage analysis must be made to determine the resisting load required of the berm. Downstream slope stability of the embankment will normally increase because of the resistance to sliding provided by the berm.

b) Remedial measure for slope stability

1) Eradicating oversized material from the catastrophe part and tamping with same materials.

2) Providing berms to improve the stability of an embankment dam.

3) Cover the downstream slope with grass in order to protect beside the erosive action of rain and runoff.

\section{Conclusion and Recommendation}

\subsection{Conclusion}

The main objective of this study is to assess ArjoDedessa embankment dam, focusing on seepage and slope stability analysis and to put possible remedial measure. Analysis of seepage quantity was done using seepage analysis methods by Darcy's phreatic line and seep/w software model analysis. The outcome shows that the value 
of seepage estimated in the design document is higher than the computed value of seepage at both full reservoir level and current water level.

Slope/w software model used to calculate the factor of safety under the standard loading conditions for limit equilibrium methods (Morgenstern-Price, Bishop, Janbu and Ordinary) using entry- exit trial slip surface and compared with the international standards and stated in design document. The outcome shows the dam was safe under this loading condition. However, from the field observation, the downstream side slope was disastrous. Causes of instability of the side slope in the downstream are the use of oversized stones of shell material and wrong placement of stones in the downstream of the dam.

\subsection{Recommendation}

The analysis was carried out to assess seepage and slope stability using the available data from the observed and design document. Therefore the following recommendations should be under consideration:

Identification on the source seepage failure needs an extensive re- analysis with help of frequent field visit and at change on upstream water level, the study area has exposed for such failure, therefore, for further detail investigation the amount of seepage should be measured at downstream of the dam and Installing dam monitoring instruments, frequent instrument reading and making observation use to provide data and information which can be used to assess the performance of the dam under normal and extreme loading condition and to manage the risk associated with operation and maintenance.

The Arjo-Dedessa dam was highly exposed to soil erosion at the slope surface problem due to the absence of soil conservation structures on the areas. In order to prevent soil erosion at the slope surface, the vegetation and trees on the existing slopes must be preserved and Surface water must be directed away from the slope or carried down the slope in suitable conduits.

\section{References}

[1] Aryal, K. P. (2006). Slope stability evaluations by limit equilibrium and finite element methods.

[2] Athani, S. S., Solanki, C. H. and Dodagoudar, G. R. (2015). Seepage and stability analyses of earth dam using finite element method. Aquatic Procedia, 4, pp. 876-883.

[3] Hordofa, K. (2015). Gefersa II embankment dam hydraulic failure, addis ababa.

[4] Garg, S. K. (2005). Irrigation engineering and hydraulic structures. Delhi. ninteenth edition.

[5] GEO-SLOPE International. Ltd. (2018). stability modelling with Geostudio. Canada.

[6] OWWDSE.( 2017). Arjo- dhidhessa design report.

[7] Redda, H. (2016). Evaluation of embankment dam failure and remedial measureAddis Ababa.

[8] Rajeeth, A. (2011). Failure of an Earth Dam. Oslo.

[9] Omofunmi, O. E., Kolo, J. G., Oladipo, A. S., Diabana, P. D. and Ojo, A. S. (2017). A review on effects and control of seepage through earth-fill dam.

[10] Saluja, I. S., Athar, M. and Ansari, S. A.(2018). Causes of Failure of Earthen Dams and suggested Remedial Measures.

[11] Tadesse, D. (2017). High embankment dam alternative design and analysis, Addis Ababa.

[12] Tumoro, M. (2010). Characterization and Suitability Analysis of Embankment Material. Addis ababa.

[13] Umaru A. B. (2014). Sangodoyin A. Y2 and Oke I. A On the Causes and Effects of Earth Dams Failures in North-Eastern Nigeria. International Journal of Engineering Research \& Technology. Vol. 3. - pp. 2278-0181.

[14] Yazdanian, M., Afshoon, H. R., Ghasemi, S., Afshoon, V. and Fahim, F. (2017). Effect of height on the static stability of heterogeneous embankment dams. Selçuk Üniversitesi. 5 (3), pp. 274-282. 